\title{
A Comparative Study on the Effects of Methylprednisolone Concentration on Human Chondrocyte Cell Metabolism in vitro
}

\author{
George Jacob ${ }^{1}$, Shetty $\mathrm{V}^{1}$, Shetty $\mathrm{SM}^{1}$, Varughese $\mathrm{J}^{2}$, Singh. $\mathrm{RP}^{3}$, Malgatti $\mathrm{SS}^{3}$ and Kadage $\mathrm{V}^{3}$ \\ ${ }^{1}$ Department of Orthopedics Justice KS Hegde Medical Academy, Nitte University Deralakatte, India \\ ${ }^{2}$ Department of Orthopedics VPS Lakeshore Hospital, India \\ ${ }^{3}$ Regenerative medical services Pvt Ltd, 22, Shah industrial Estate, India
}

Submission: March 05, 2017; Published: March 10, 2017

*Corresponding author: Dr George Jacob, 3B Link Heights, Panampilly Nagar, Cochin, Kerala 682036, India, Tel: +919591524660;

Email: drgeorge.jac@gmail.com

Abstract

Introduction: Osteoarthritis of the knee has been the most common form of arthritis encountered by clinicians today. Conservative modalities such as non steroidal anti inflammatory medications and intra articular corticosteroid have been employed to ameliorate the symptoms and delay total knee arthroplasty. In the past Corticosteroids have had an important role to play for decades in effective, economic and symptomatic relief in arthritis, but it may mask its true impact on the joint. The purpose of this study is to identify the effects of the concentration of methyl prednisolone on chondrocyte cell count, viability and CD44+ expression.

Materials \& Methods: Three cartilage bone plugs were harvested from three patients suffering from osteoarthritis scheduled for total knee arthroplasty. Chondrocytes were isolated and cultured to passage one and three samples from passage one cultured to passage two. Flasks were seeded with $1 \mathrm{uM} / \mathrm{ml}, 10 \mathrm{uM} / \mathrm{ml} \& 100 \mathrm{uM} / \mathrm{ml}$ of methyl prednisolone against control. Cells were harvested on day 14 of culture and assessed for cell viability, count and CD 44+ expression. Statistical analysis was done with ANOVA test and post hoc test, a P value of 0.05 was taken to be significant.

Result: Cell count in the both passage 1 and 2 cultures decreased with increasing methylprednisolone concentration. The decrease in cell count in passage 2 was noted to be significant $(\mathrm{P}=0.013)$. Cell viability reduced in both passage with increased concentration of methylprednisolone with the decrease in passage 2 being significant $(\mathrm{P}=0.011)$. CD44+ expression decreased with increasing methyl prednisolone concentration in both passages, but the reduction was not significant.

Conclusion: Methyl prednisolone has a dose dependent negative effect on chondrocyte cell viability, count and CD44+ expression. Hence may not be an ideal drug for the treatment of osteoarthritis knee.

Keywords: Methyl Prednisolone; Osteoarthritis; Chondrocytes; Cartilage; Corticosteroid

\section{Introduction}

Osteoarthritis of the knee has been the most common form of arthritis encountered by clinicians today [1]. Many conservative treatment modalities have been employed to ameliorate the symptoms and delay total knee arthroplasty. Non steroidal anti inflammatory medications and corticosteroid treatments have been the bulk of the conservative treatments used to alleviate the pain and inflammation. Nutraceuticals such as chondroitin sulphate and glucosamine have been launched in the last decade along with intra-articular hyaluronic acid injections and platelet rich plasma.
Steroids have had an important role to play for decades in effective, economic and symptomatic relief in arthritis, but it may mask its true impact on the joint. According to 2015 Cochrane review intra-articular corticosteroids may cause a moderate improvement in pain and a small improvement in physical function, but the quality of the evidence is low and results are inconclusive.

The purpose of this study is to identify the effect of methyl prednisolone and its concentration on chondrocytes in vitro. We aim to assess any changes that may occur in cell count 
and viability when exposed to various concentrations of corticosteroid.

CD 44+ receptors are responsible for detecting extra cellular matrix changes and regulating chondrocyte metabolism [2]. The expression of CD44+ is an indicator of the chondrocyte metabolic activity and collagen production [3]. Our hypothesis is that as the concentration of methyl prednisolone increases there will be decreased cell count, viability and collagen synthesis.

\section{Methods and Materials}

\section{Tissue Culture and Harvest}

All procedures were approved under the institutional ethical committee and with patients informed consent. Three cartilage bone plugs were harvested during total knee arthroplasty from patients suffering from osteoarthritis scheduled for surgery under sterile conditions. Chondrocytes were isolated and cultured to passage one and three samples from passage one cultured to passage two.

Passage one and two flasks were seeded with $1 \mathrm{uM} / \mathrm{ml}, 10$ $\mathrm{uM} / \mathrm{ml} \& 100 \mathrm{uM} / \mathrm{ml}$ of methylprednisolone against control. Cells were then harvested on the 14th day of culture and assessed for cell viability, cell count, CD 44+ expression.

\section{Cell Viability}

$20 \mu$ l Samples of cell suspension was removed on the 14 th day culture and dispensed into a $1.4 \mathrm{ml}$ test tube. A hemocytometer was wiped with 70\% isopropyl alcohol and allowed to dry. $20 \mu \mathrm{l}$ of $0.4 \%$ Trypan blue was added to the same test tube and the mixture gently mixed by dispensing with a micropipette. $10 \mu \mathrm{l}$ of the cell suspension Trypan blue mixture is then transferred to the counting chamber under a cover slip. Stained cell (non viable) and non stained cells (viable) are then counted in 4 squares of the hemocytometer areas at 100x magnification [4]. The percentage of the viable cells is then calculated by dividing the viable cells by total cells and multiplied by one hundred.

\section{Cell Count}

Aperture of the coulter counter is first flushed. $200 \mu$ l of the culture sample is removed from the cell suspension. It is then dispensed in $9.8 \mathrm{ml}$ of cell counting buffer and mixed well. The sample is then poured into an accuvette sample container and then placed on the coulter counter platform. The aperture is then immersed into the cell suspension. The coulter counter is then initiated and a reading taken and recorded.

\section{44+ Expression}

\section{Measured using flowcytometry}

\section{Specimen preparation}

$100 \mu \mathrm{l}$ of well mixed specimen brought to room temperature is added to tube. $10 \mu \mathrm{l}$ of antibody solution is added to the mixture. The sample is then incubated for 30 minutes in a dark room at room temperature. The cells were then washed twice with BD FACSFlow Solution. The sample was then centrifuged at $1500 \mathrm{rpm}$ for 5 minutes. The supernatant is then discarded and the pellet suspended in $500 \mu$ l of BD FACSFlow solution. The sample is then run through the flow cytometry within one hour and readings recorded.

\section{Results}

\section{Cell Count}

Cell count in the both passage 1 and 2 cultures decreased with increasing methylprednisolone concentration (Figure 1). The decrease in cell count in P2 was noted to be significant $(\mathrm{P}=0.013)$ (Table 1).

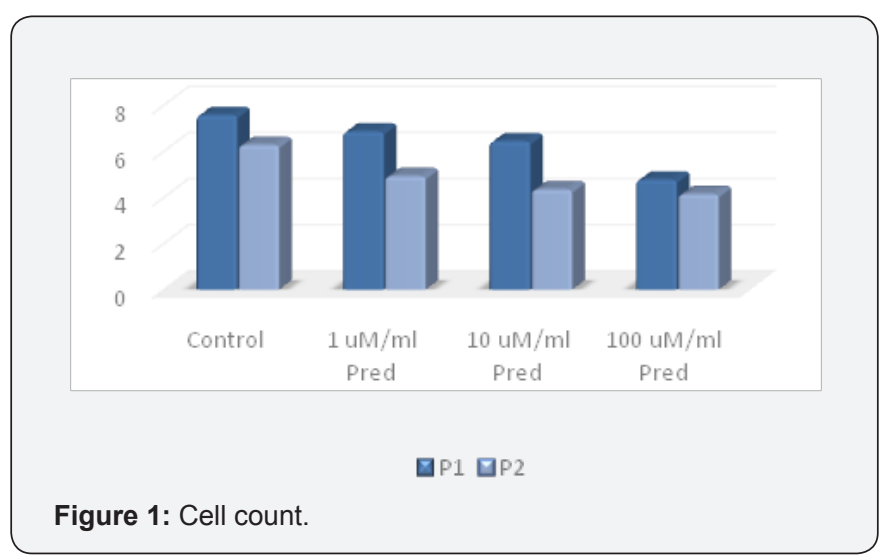

Table 1: Cell Count.

\begin{tabular}{|c|c|c|c|c|c|}
\hline \multicolumn{6}{|c|}{ Cell Count } \\
\hline & $\begin{array}{c}\text { cultural } \\
\text { stage }\end{array}$ & Mean & sd & $\mathbf{F}$ & $P$ value \\
\hline Control & $P_{1}$ & 7.573 & 2.62 & \multirow{4}{*}{.608} & \multirow{4}{*}{.629} \\
\hline $1 \mathrm{uM} / \mathrm{ml}$ Pred & P1 & 6.8567 & 3.025 & & \\
\hline $10 \mathrm{uM} / \mathrm{ml}$ Pred & P1 & 6.4333 & 3.29 & & \\
\hline $100 \mathrm{uM} / \mathrm{ml}$ Pred & P1 & 4.7700 & 1.09 & & \\
\hline Control & P2 & 6.2800 & 1.22 & \multirow{4}{*}{$6.68^{* *}$} & \multirow{4}{*}{.013} \\
\hline $1 \mathrm{uM} / \mathrm{ml}$ Pred & P2 & 4.9233 & 240 & & \\
\hline $10 \mathrm{uM} / \mathrm{ml}$ Pred & P2 & 4.3467 & .190 & & \\
\hline $100 \mathrm{uM} / \mathrm{ml}$ Pred & $P_{2}$ & 4.1433 & 142 & & \\
\hline
\end{tabular}

\section{Cell Viability}

It was seen that cell viability was reduced in both P1 and P2 cultures (Figure 2) with a significant reduction in viability with increased methyl prednisolone concentration in the P2 culture $(\mathrm{P}=0.011)$ (Table 2).

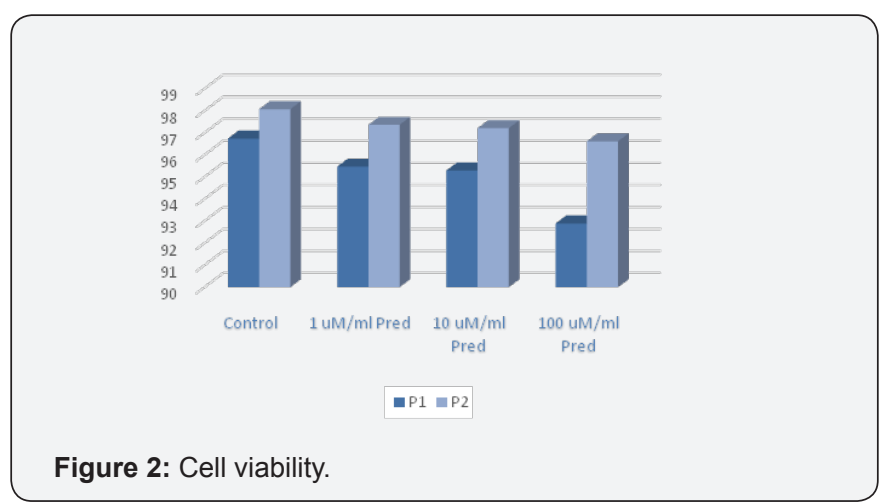


Table 2: Concentration of Steroid in cell viability. Concentration of Steroid in Cell Viability

\begin{tabular}{|c|c|c|c|c|c|}
\hline & $\begin{array}{c}\text { cultural } \\
\text { stage }\end{array}$ & Mean & sd & $\mathrm{F}$ & $P$ value \\
\hline Control & P1 & 96.7400 & 1.64654 & \multirow{4}{*}{$.530^{\circ}$} & \multirow{4}{*}{.674} \\
\hline $1 \mathrm{uM} / \mathrm{ml}$ Pred & P1 & 95.4667 & 2.65581 & & \\
\hline 10 uM/ml Pred & P1 & 95.2933 & 3.66814 & & \\
\hline $100 \mathrm{uM} / \mathrm{ml}$ Pred & P1 & 92.8933 & 5.92655 & & \\
\hline Control & P2 & 98.0700 & .38105 & \multirow{4}{*}{$7.27^{* *}$} & \multirow{4}{*}{.011} \\
\hline $1 \mathrm{uM} / \mathrm{ml}$ Pred & P2 & 97.3633 & .37554 & & \\
\hline $10 \mathrm{uM} / \mathrm{ml}$ Pred & P2 & 97.2133 & .16862 & & \\
\hline $100 \mathrm{uM} / \mathrm{ml}$ Pred & P2 & 96.6167 & .52310 & & \\
\hline
\end{tabular}

\section{44+ Expression}

With increased methyl prednisolone concentration there is a reduction in $\mathrm{CD}+44$ expression in both $\mathrm{P} 1$ and P2 culture (Figure 3) but not significant in either groups (Table 3).

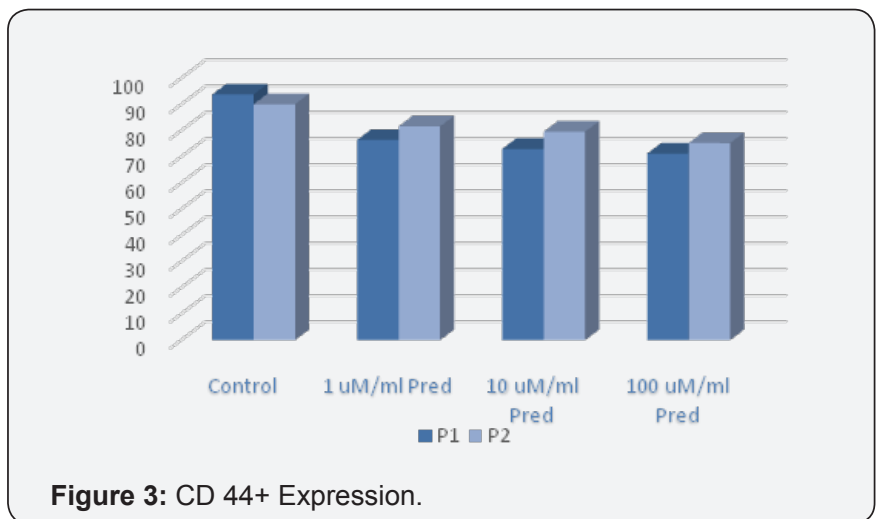

Table 3: Concentration of steroid in CD44 expression.

Concentration of Steroid in CD 44 Expression

\begin{tabular}{|c|c|c|c|c|c|}
\hline & $\begin{array}{c}\text { cultural } \\
\text { stage }\end{array}$ & Mean & sd & $\mathrm{F}$ & $P$ value \\
\hline Control & P1 & 93.7933 & 3.14662 & \multirow{4}{*}{$1.82^{*}$} & \multirow{4}{*}{.220} \\
\hline $1 \mathrm{uM} / \mathrm{ml}$ Pred & P1 & 76.4533 & 14.42776 & & \\
\hline $10 \mathrm{uM} / \mathrm{ml}$ Pred & P1 & 73.0367 & 15.36646 & & \\
\hline $100 \mathrm{uM} / \mathrm{ml}$ Pred & P1 & 71.2467 & 15.71900 & & \\
\hline Control & P2 & 90.1000 & 4.70698 & \multirow{4}{*}{$2.91^{\circ}$} & \multirow{4}{*}{.111} \\
\hline $1 \mathrm{uM} / \mathrm{ml}$ Pred & P2 & 81.6200 & 7.94906 & & \\
\hline $10 \mathrm{uM} / \mathrm{ml}$ Pred & P2 & 79.5733 & 7.34406 & & \\
\hline $100 \mathrm{uM} / \mathrm{ml}$ Pred & P2 & 75.2600 & 4.52516 & & \\
\hline
\end{tabular}

*not significant $(\mathrm{p} ;<0.05)$

\section{Discussion}

Out study was aimed at determining whether methyl prednisolone was beneficial or toxic to chondrocytes.

As the concentration of methyl prednisolone increases, the cell count in both passage 1 and 2 cultures reduced in our study. However, the reduction was statistically significant only in passage 2 culture ( $p$ value $=0.013$ ). Cell viability decreased as the concentration of methyl prednisolone increased in both passage cultures with a statistically significant decrease in passage 2 cultures $(\mathrm{P}=0.011)$. CD44+ expression was found to be reduced in both passages though not statistically significant.
A study done by Dragoo et al. [5] comparing dexamethasone and methyl prednisolone showed similar chondrotoxic results in both dexamethasone and methyl prednisolone group [5]. These results are comparable to our study which also showed similar chondrotoxic features as shown by decreased cell count, cell viability and CD44+ expression. Sherman et al. [6] in an in vitro study on canine cartilage demonstrated significant loss of chondrocyte and synoviocyte viability when exposed to corticosteroids [6]. It is understood that apoptosis of chondrocytes hastens the onset of joint arthritis [7]. With effects of chondrocyte apoptosis the corticosteroid injections would be hastening joint arthritis.

A systematic review done by Braun et al. [8] revealed a large dose-dependent deleterious effect on chondrocytes with catabolic effects on protein levels, chondrocyte viability and gross cartilage morphology [8]. Our results showed similar findings with regard to chondrocyte viability.

Limitations in our study were that we only tested three concentrations $(1 \mathrm{uM} / \mathrm{ml}, 10 \mathrm{uM} / \mathrm{ml} \& 100 \mathrm{uM} / \mathrm{ml})$ of the drugs while there are steroid preparations of varied strengths available in the market. Ideally the average joint surface area of a person should be determined. Concentrations for in vitro studies could be better determined by averaging the total cartilage surface area in the human knee with quantitative imaging.

\section{Conclusion}

This study proves that methyl prednisolone has a dose dependent negative effect on chondrocytes cell viability, cell count and CD44+ expression and hence may not be ideal drug for the treatment of osteoarthritis knee.

\section{References}

1. Felson DT, Lawrence RC, Dieppe PA, Hirsch R, Helmick CG, et al. (2000) Osteoarthritis: new insights. Part 1: the disease and its risk factors. Ann Intern Med 133(8): 635-646.

2. Takahashi N, Knudson CB, Thankamony S, Ariyoshi W, Mellor L, et al. (2010) Induction of CD44 cleavage in articular chondrocytes. Arthritis Rheum 62(5): 1338-1348.

3. Knudson CB, Knudson W (2004) Hyaluronon and CD44: modulators of chondrocyte metabolism. 6 Clin Orthop Relat Res (427 Suppl): S152-S162.

4. Strober W (2015) Trypan Blue Exclusion Test of Cell Viability Current protocols in immunology 2 NOV 2015.

5. Dragoo JL, Danial CM, Braun HJ, Pouliot MA, Kim HJ (2012) The chondrotoxicity of single dose corticosteroids. Knee sports Traumatol Arthrosc 20(9): 1809-1814.

6. Sherman SL, Khazai RS, James CH, Stoker AM, Flood DL, et al. (2015) In Vitro Toxicity of Local Anesthetics and Corticosteroids on Chondrocyte and Synoviocyte Viability and Metabolism. Cartilage 6(4): 233-240.

7. Hashimoto S, Robert L Ochs, Komiya S, Lotz M (1998) Linkage of chondrocyte apoptosis and cartilage degeneration in human osteoarthritis. Arthritis Rheum 41(9): 1632-1638.

8. Braun JH, Dragoo JL Systematic Review; The Effect of Intra-Articular Corticosteroids on Articular Cartilage performed at Stanford University, Redwood City, California, USA. 
This work is licensed under Creative Commons Attribution 4.0 License

DOI: 10.19080/OROAJ.2017.05.555660

\section{Your next submission with Juniper Publishers} will reach you the below assets

- Quality Editorial service

- Swift Peer Review

- Reprints availability

- E-prints Service

- Manuscript Podcast for convenient understanding

- Global attainment for your research

- Manuscript accessibility in different formats

( Pdf, E-pub, Full Text, Audio)

- Unceasing customer service

Track the below URL for one-step submission https://juniperpublishers.com/online-submission.php 